\title{
Organizasyon Bilgi Sistemleri Odağında Finansal Bilgi Sistemi ve Bir
} Analiz

\author{
Duygu DEMIRHAN ${ }^{1 *(D)}$, Yılmaz GÖKŞEN ${ }^{2}$ (D) Hakan AŞAN $^{3}$ \\ ${ }^{1}$ Data Analyst, Batıgöz Health Group, İzmir, Turkey \\ ${ }^{2}$ Prof. Dr., Dokuz Eylül University, Faculty of Economics and Administrative Sciences, Department of \\ Management Information Systems, İzmir, Turkey \\ ${ }^{3}$ Research Asst., Dokuz Eylül University, İzmir Vocational School / Economic and Administrative Programs, \\ İzmir, Turkey
}

Geliş Tarihi/Received: 09.02.2021

Kabul Tarihi/Accepted: 08.03.2021
Doi: $10.31200 /$ makuubd.877241

Araştırma Makalesi/Research Article

\section{ÖZET}

Teknolojik alandaki gelişimler öncelikli olmak üzere oluşan her değişme/gelişme organizasyonlar üzerinde yapısal anlamda dönüşümlerine sebep olmaktadır. $\mathrm{Bu}$ dönüşme organizasyonlarda yataylaşma gerçekleştirerek tüm birimlerinin bilgi sistemleri halinde kategorize olmalarını sağlamaktadırlar. Bu dönüşüm ile birlikte organizasyon bilgi sistemleri kavramsal olarak ortaya çıkmaktadır. Bu sistemler organizasyonun tüm birimleri açısından, organizasyonun ortak hedeflerine göre aralarında iletişim halinde olan, birbirlerinin oluşturdukları raporlara gereksinim duyan sistemlerdir. Çalışma içinde organizasyon bilgi sistemleri arasından finansal bilgi sistemlerine odaklanılmaktadır. Devamında ise organizasyon bilgi sistemleri temel hatları ile ele alınmış; finansal bilgi sistemlerinin işleyişleri, oluşturdukları raporlar ve bu raporların yönetsel kararlar üzerindeki etkilerinden söz edilmiştir. Çalışma, bu kapsam dâhilinde ilerletilmiş ve otomotiv sektöründe faaliyet gösteren, sac parça üretimi ve kalıpçılık alanında uzmanlaşmış bir üretim firması için yeni bir uygulama geliştirilmiştir. Bu aşamada mevcuttaki işleyiş̧in otomatize edilmesinin yanı sıra işleyişe bağlı olarak gerçekleştirilmesi gerekli iş akışlarının yürütülmesi ve farklı birimler ile iletişimlerinin kurulması hedeflenmektedir. Yapılan çalışma sonucunda işlem kayıpları ve gecikmelerine yol açan geleneksel biçimde yürütülen bir operasyon otomatize edilmiş ve kendisinden sonraki birimlere ise veri/bilgi geçişini sağlayacak süreçler entegre edilmiştir. Bunların sonucunda ise tüm departmanları içine alan bu entegrasyon sayesinde anlık ve gerçek raporlara ulaşılarak

* Sorumlu yazar/Corresponding author

E-mail/e-ileti: duygu.demirhan1@gmail.com 
yöneticilerin rasyonel kararlar almaları sağlanabilmektedir. Bu sayede işlerin etkinliği, hızı ve verimliliği artırılmaktadır. Önerilen sistem kullanıldıkça ortaya çıkan olası sorunlar ya da öngörülen iyileşme izlendikçe gerçekleşen olumlu gelişmeler ile değerlendirme sonucu ortaya çıkacaktır. Uygulama aktif kullanıldıkça, veri girişleri gerçekleştikçe görülen olumlu gelişmeler sistemin en temel geri bildirimi bildirimi olarak işlenecektir.

Anahtar kelimeler: Bilgi Sistemleri, Organizasyon Bilgi Sistemleri, Finansal Bilgi Sistemleri, Finansal Raporlar, Maliyet Analizi.

\title{
Financial Information System in The Focus of Organizational Information System and An Analysis
}

\begin{abstract}
Every change/development, especially in technological environment, causes the organizations to undergo a structural transformation. This transformation horizontalizes the organizations so that each unit is categorized into information systems. At this stage, the concept of organization information systems is formed as a result of transformation. These systems are the systems that are in communication with each other in line with the common goals of the organization and need each other's reports for each unit of the organization. In the study, the scope of financial information system, which is one of the systems mentioned, is focused on. Afterwards, by mentioning organizational information systems in general strokes, operation of financial information systems, their reports and the effects of these reports on managerial decisions are referred. By improving the study within this scope, a new application has been developed for a company which is active in sheet metal production and molding industry in automotive sector. At this stage, it is aimed to both automate the current work and ensure the communication with different units by conducting the workflows that should be realized in connection with this work. As a result of the study, an operation which was carried out in a traditional manner leading to transaction losses and delays was automated. The processes that will enable data/information transfer to have been integrated to the subsequent units. As a result, thanks to this integration that includes all departments, instant and real reports can be reached, and managers can make rational decisions. Thus, the efficiency, speed and productivity of the works are increased. Possible problems that arise as the proposed system is used, or positive developments as the anticipated improvement is followed, and the evaluation result will emerge. As the application
\end{abstract}


is actively used, positive developments seen as data entries take place will be processed as the most basic feedback of the system.

Keywords: Information Systems, Organization Information Systems, Financial Information Systems, Financial Reports, Cost Analysis.

\section{GIRIŞ}

Organizasyonlar teknolojinin etkisi ile birlikte yapısal olarak dönüşüm geçirmektedirler. Her organizasyon ulusal ve uluslararası rekabette avantajlı hale gelebilmek için bilgi sistemleri kullanarak iş yapma biçimlerini ortak bir veri tabanı temelinde standart bir işleyişe dönüştürmektedir.

Bilgi sistemleri, organizasyonların tüm birimleri için, ortak kurumsal hedefler doğrultusunda birbirleriyle iletişimde olan, birbirlerinin ürettikleri raporlara ihtiyaç duyan sistemlerdir. Bu bakışla organizasyon bilgi sistemlerinden biri olan finansal bilgi sistemleri çerçevesinde bilimsel bir çalışma ortaya konması hedeflenmektedir. Organizasyondaki tüm departmanlar kendi içlerindeki ve birbirleri aralarındaki işleyiş planlarında uyguladıkları eylemlerin standart hale getirilmesi konusunda belli bir tabana oturtma eğilimine girmektedirler.

Organizasyonların içsel yapıları üzerinde değişime elverişli halde olmalarındaki en büyük etkenlerden birisi bilgi teknolojilerinin gün geçtikçe gelişmekte olması durumudur (Güney, 2014: 04). Organizasyon yapılarında gerçekleşmekte olan bu değişim ile organizasyonlar üstünde dikeyden yataya bir yapılaşma görülmesi sağlanmaktadır (Aksay, 2015: 111).

Organizasyonlar sadece kurulum aşamasında ele alınacak bir kavramdan ziyade, organizasyonun yaşamı boyunca üzerinde olması gereken bir disiplinle devamlı şekilde gözden geçirilmesi ve geliştirilmesi gereken bir düzen olarak düşünülmelidir (Çubukçu, 2018: 186).

Laudon'a (2014) göre organizasyon; kendi çevresinden edinmiş olduğu kaynakları işlemesiyle çıktı haline getiren, dengeli şekilde ve belli bir biçimsellik halinde bir yapı olarak tanımlanmıştır. Teknik olarak yapılmış bu tanım ile üç işlev temel gösterilmiştir. Sermaye, emek ve organizasyonun kendi çevresinde bulunan temel üretim faktörleridir (Laudon ve Laudon, 2014: 82). Karahan (2008) ise organizasyonun; belli hedeflerin etkin ve etkili olarak 
sağlanabilmesi amacıyla belirli özellikteki kişilerin topluluk oluşturan ve oluşturdukları çevre ile devamlı olarak iletişimde olan yapılar olduğunu tanımlamaktadır (Karahan, 2008: 457).

Organizasyonlar bünyeleri içindeki tüm alanlardan bilgiler bulundurmakta ve verimliliklerinin artırılarak amaçlanan performanslarına ulaşabilmesi hedefiyle bu bilgilerin sistematik şekilde düzenlenmelerini sağlamak durumundadırlar. $\mathrm{Bu}$ doğrultuda yapısal anlamdaki kategorizasyon sonucunda organizasyon bilgi sistemleri kavramı oluşmaktadır. Organizasyon Bilgi Sistemleri, bünyesinde bulunan bilginin yönetiminin gerçekleştirilmesi ve bu bilgiler sonucu oluşacak raporlarla rasyonel kararların verilebilmesi ve iş süreçlerinin yönetilmesine destek veren sistemler olarak tanımlanmaktadır.

Teknolojinin söz edilen bu etkileri birbirleriyle ilişkilendirilmiş halde iki nitelikte gösterilmiştir. Birinci etkisi; teknolojinin rekabet hızındaki yükselişine, hizmetlerindeki iyileştirme çalışmaları için müşteri isteklerine, oluşabilecek güvenlik konusundaki tehditlere karşı organizasyonların tedbirli olmalarının sağlanması gibi konularda hizmette bulunabilmeleridir. İkinci etkisi ise; teknolojinin organizasyon üzerindeki iş süreçlerinin ve organizasyon içindeki karmaşanın yönetilmesine destek sağlaması olarak belirtilmiştir. Karmaşıklaşan organizasyon içindeki iş akışlarının yanında, organizasyonun dış çevreyle olan iş süreçlerinin yürütülmesine de destek sağlamaktadır (Onat, 2007: 100-101).

Teknolojinin etkileriyle bilgi sistemleri halinde kategorize olan bu sistemler organizasyonun her birimi için, organizasyonun ortak amaçları yönünde birbirleriyle iletişim halinde olan, birbirleri aralarındaki raporlara gereksinim duyan sistemler; Satış ve Pazarlama Bilgi Sistemleri, Üretim ve İmalat Bilgi Sistemleri, İnsan Kaynakları Bilgi Sistemleri ve Finansal Bilgi Sistemleri olarak sıralanmaktadır.

Çalışmada, gözlemlenen problemlere göre bu organizasyon bilgi sistemleri arasından finansal bilgi sistemine odaklanılmış, bu çerçeve dâhilinde bilimsel bir çalışma ortaya konması hedeflenmektedir. Organizasyonların belli zaman döngüsü içinde birimler arasındaki iletişimleri, birbirlerine olan rapor çıktıları, birimin kendisiyle alakalı kararların doğru bir şekilde alınabilmesi için gerekli bilgileri oluşturmalarında önemli bir rol oynamakta oldukları gözlemlenmektedir.

Günümüzde finans alanının gelişmeleri incelendiğinde ise yakın planda görülen belli noktalar bulunmaktadır. Başta bilişim ve iletişim teknolojileriyle birlikte artmakta olan küreselleşme, finansal entegrasyon konusunun da oluşmasını sağlamıştır (Morgül, 2013). Bu 
entegrasyonun, organizasyonların bütün birimlerinden oluşacak olan raporların anlık gelişmelerde dahi doğruluğunun artırılmasını ve bununla beraber kararların rasyonelleştirilmesini kolaylaştırdığını göstermektedir.

$\mathrm{Bu}$ bağlamda değerlendirildiğinde finansal bilgi sistemlerinin temel hedeflerinden birisinin organizasyonun amaçlarına ulaşmasındaki başarıya fırsat yaratılması olduğu söylenebilir. Finansal bilgi sistemlerinin organizasyonun içinde oluşacak doğru bilginin akışının sağlanabilmesi, oluşabilecek risklerin ve alınacak inisiyatiflerin boyutunun belirlenebilmesi, erken uyarı sistemlerinin yaratılması, olasılık dahilindeki krizlerde hazırlıklı halde bulunma durumunun sağlanması, oluşturulan planlamaların resmileştirilip krizleri önleyecek gruplar oluşturulması gibi amaçları bulunmaktadır (Demir ve Coşkun, 2009: 4-5). $\mathrm{Bu}$ yüzden organizasyon içinde yönetsel kararların bilimsel olarak alınabilmesi için finansal bilgilere önemli ölçüde ihtiyaç olmaktadır (Yılmaz, 1999: 52).

Finansal bilgi sistemi organizasyonda yönetimsel anlamda güçlü performansta, güvenilirlikle ve doğru zamanlı bilginin sağlanması görevindeki sistemlerdir.

Finansal bilgi sistemleri, stoklama, satış ve alacak, ücretlendirme, maliyetlendirme ve kontrol, bütçe belirleme, gelir ve giderler ile alakalı işlemleri kapsamakta olan alt sistemler halinde bulunmaktadır (Sürmeli'den aktaran Bekçi ve Alkan, 2009: 3)

$\mathrm{Bu}$ doğrultuda, finansal bilgi sistemlerinin en önemli amacı, organizasyonların sınırlarında ve dışında olan birey ve grup için gereken bilgilerin sağlanması olarak belirtilmektedir (Bagranoff vd., 2005: 13).

Belirtilen bu bilgilerce finansal bilgi sistemlerinin, organizasyonun yapı ve özellikleri açısından genel anlamda genel ve finansal muhasebe veya maliyet muhasebesi gibi temel muhasebe yapısını da kapsadıkları gözlemlenmektedir.

Finansal bilgi sistemi bunların yanı sıra organizasyonun kıt kaynaklarının optimal dağılımlarının sağlanmasında ve organizasyon amaçlarına ulaşımda yardım edecek şekilde, kullanıcı bilinçlendirmesi sağlanarak karar verme konusunda olanak yaratma üzerine belirli bir yapı üretilerek ilgili kullanıcıya ulaştırılması işlemlerinin organize edilmesini sağlayan sistemlerdir (Usul ve Bekçi, 2001: 69).

Günümüzde bilgi ihtiyacı gittikçe kullanıcı yönünden artmaya devam ederken, bilginin erişimi ve erişilmiş olan bilginin karar vermedeki süreçlerde etkili kullanımında yaşanan 
sorunların ve organizasyonun sektör rekabetlerinde avantaj sağlama çabalarının bilgi sistemlerine odaklanılmasına sebebiyet vermektedir. Yönetim süreçleri ve karar verme eyleminin bilgi sistemleri yönünden etkilenmeleri geçmişten bu zamana dek kabul görmüş ve beraberinde bilgi teknolojileri konusundaki gelişmeler bilgi sistemleri üzerinde yapılanma ve faaliyetler kapsamında genişletilmelerine neden olmaktadır (Alagöz vd., 2013: 38). Yönetsel kararlarda etkisi olan bilgi topluluklarının çoğu organizasyonun finansal durumunu, faaliyetlerinin sonucunu ve bu sonuçların oluşumunu gösteren bilgiler olduğundan, finansal bilgi sistemlerinin organizasyon yönetiminde yakından etkilediği görülmektedir (Bölükoğlu ve Birgili, 1992: 74).

Finansal raporların bünyesindeki bu bilgilerin organizasyonun karar vericileri yönünden gereken zamanda ve verimli şekilde kullanılmaları nedeniyle raporları oluşturan bilgi kümelerinin kaliteli verilerden oluşmaları gereklidir. Bu bilgi kalitesini belirleyen etmenler; anlaşılabilirlik, ihtiyaçların karşılanmasında uygunluk, önem ve güvenilirlik düzeyleri, doğru zaman ve tarafsızlıklarıdır (Demir, 1996: 5).

Organizasyondaki finansal raporlar ve taşıdıkları özelliklerle birlikte bu raporların kullanıcı tarafındaki kısıtları aşağıdaki gibi belirtilmiştir (Akdoğan ve Tenker, 2001: 37-38):

- Genel hedefleri bulunmaktadır.

- Bu hedefler kapsamında uygunluk durumlarına göre gruplanırlar.

- Birden çok işlem raporunu özetleyerek sunabilirler.

- Herhangi bir finansal rapor üzerinde farklı değerlendirmeler yapılmış, farklı yöntemler kullanılmış olabilir.

- Oluşturuldukları ülkenin para biriminde hazırlanırlar.

- Nakit esaslarındansa bu raporlar gerçekleşme esrarları kapsamında hazırlanmaktadır.

Finansal bilgi sistemleri, organizasyondaki departmanlar arasındaki iletişim kopukluklarının çözümlenmesini sağlayabilen koordine edici fonksiyonunun organizasyondaki tüm departmanların uyumlu halde ve etkili halde çalışabilmesinde etkin olduğu görülmektedir. $\mathrm{Bu}$ fonksiyon, yönetsel karar vermenin dışında düzenleyici karar alma kademelerinde de organizasyon için önemli noktada bulunmaktadır (Demir ve Coşkun, 2009: 7). 
Finansal bilgi sistemleri çıktısı olan finansal raporlar organizasyonun yönetsel kararlarındaki verimlilik, doğruluk, hızlılık gibi önem içeren parametrelerin sağlanmasındaki etkilerinin sonucunda organizasyon departmanları arasında gereken iletişimin kurulmasında yardımcı olarak kararlarının organizasyonun ortak amaçları kapsamında alınmasında rol oynadığı görülmüştür.

Tanımlardan anlaşıldığı üzere organizasyonda yönetsel yönden güçlü performans içindeki finansal bilgi sistemleri; doğru ve güvenilir bilginin oluşumunda etkili sistemlerdir.

Çalışmada, finansal bilgi sistemi doğrultusunda; otomotiv sektörü içinde faaliyette olan bir işletmenin, diğer işletmeler tarafından üretilmesi istenen ürünler için talep edilen fiyat teklifi adına ürünün malzemesi, operasyon adımları sonucu oluşacak işçilik süresi, firmayla anlaşmaları kapsamında genel gider oranı, hesaplanan dönem bazında ekonomik veriler baz alınarak oluşturulacak ve teklif olarak paylaşılması beklenen parça birim fiyat analizinin sistemli olarak hesaplamalarının yapılabildiği ve bu hesabın detaylarının tutulacağı bir veri tabanının bulunduğu, talep edildiğinde ise bu detaylara ulaşılabilen bir uygulama oluşturma hedeflenmiştir.

İşletmede değişik firmalardan gelecek teklif taleplerine göre maliyetlendirme çalışmaları içinde mevcut yöntem kullanılırken gözlemler sonucu tespit edilen sorunlar, olası hatalar ve bu hataların işletme için olumsuzluk yaratan sonuçlarının göz önünde bulundurulmasıyla finansal bilgi sistemi doğrultusunda yeni bir uygulamanın geliştirilmesiyle yapılacak işin otomatize edilebilmesi amaçlanmaktadır. Çalışma amacında genel hatlarla, yapılacak işlerin otomatize edilmesinin yanında işlerin sonuçlarına bağlı işletme iç ve dışı için yapılması hedeflenen bazı adımların süreçleri ve buna bağlı bilgi akışının sistemli halde ilerlemesini sağlamak bulunmaktadır.

İşletmede farklı şirketlerden gelen teklif istekleri doğrultusunda maliyet çalışmalarında mevcut yöntemde MS Office Excel üzerinden ilerlenmektedir. Bu yöntem içinde hesaplanan fiyatların kullanıcının hatasından kaynaklı hatalı sonuçlara sebebiyet verdiği gözlemlenmiştir. Bunların yanında geçmiş zamanda fiyat teklifi verilmiş benzer ürün çalışmalarının analizlerinin ulaşılmasında güçlük çekilmekte, bazı durumlardaysa veri kayıplarının yaşandığı görülmüştür. $\mathrm{Bu}$ gibi aksaklıklardan olumsuz yönde etkilenmekte olan işletme profili sektör bazındaki rekabette de zayıflayacağı öngörülmüştür. Tüm bu problemlerin çözüleceği planlanarak finansal bilgi sistemleri kapsamı içinde işlevsel bir uygulamanın hazırlanarak yapılacak işlerin otomatize ilerlemesinin sağlanması amaçlanmıştır. 
Uygulamanın hedef ve önemi temel hatları ile yapılacak işlerin otomatize edilmelerinin yanında işlerin sonuçları doğrultusunda işletme iç ve dışında bitirilmesi gerekli olan eylemlerin süreçleri ve bu yöndeki veri akışlarının da sistematikleştirilmesini sağlamaktır.

Çalışmada genel olarak; organizasyonlarda hem birim içlerinde hem de birimler arasında iş akışının sistematize edilmiş, doğru, hızlandırılmış şekilde gerçekleşebildiğine, teknolojinin gerekli yöntemlerle birlikte bilgi sistemleri kapsamı dahilinde organizasyon ihtiyaçlarına yönelik yapılabilecek gelişmeler ile daha iyi noktalara taşınabilecek bir uygulamayla örneklendirilerek sonuçlar değerlendirilmiş ve aktarılmıştır.

\section{METODOLOJİ}

Çalışma, otomotiv sektöründe Manisa Organize Sanayi Bölgesi’nin sac-metal parça ve kalıp sektöründeki faaliyet göstermekte olan gelişmiş firmalarından biri üzerinde gerçekleşmiştir. Uygulanması için hazırlanacak olan güncel maliyetlendirme analizini içeren uygulamanın hem kendi departmanında (finans) hem de diğer departmanların birbirlerinin arasındaki, olması gereken zamanlar dahilinde sağlanması gerekli bilgi akışlarını kolaylaştıracağı öngörülmüştür.

Uygulama işletim sistemi olarak Windows işletim sisteminde, Visual Studio yazılımı içinde C\# nesne yönelimli programlama dili ile hazırlanmıştır. Uygulama içindeki veri depolama alanı olarak ise MS SQL Server ilişkisel veri tabanı yönetim sistemi tercih edilmiştir. $\mathrm{Bu}$ ikisi arasında bulunan ilişkinin sağlandığ 1 teknoloji ise ORM (Object Relational Mapping) araçları içinden Entity Framework olarak seçilmiştir.

\subsection{Uygulama Aşamaları}

Uygulamanın süreç akışı ve bu akıştaki tanımlamalardan aşağıda şekil ve alt başlıklar halinde kısaca bahsedilmiştir. 


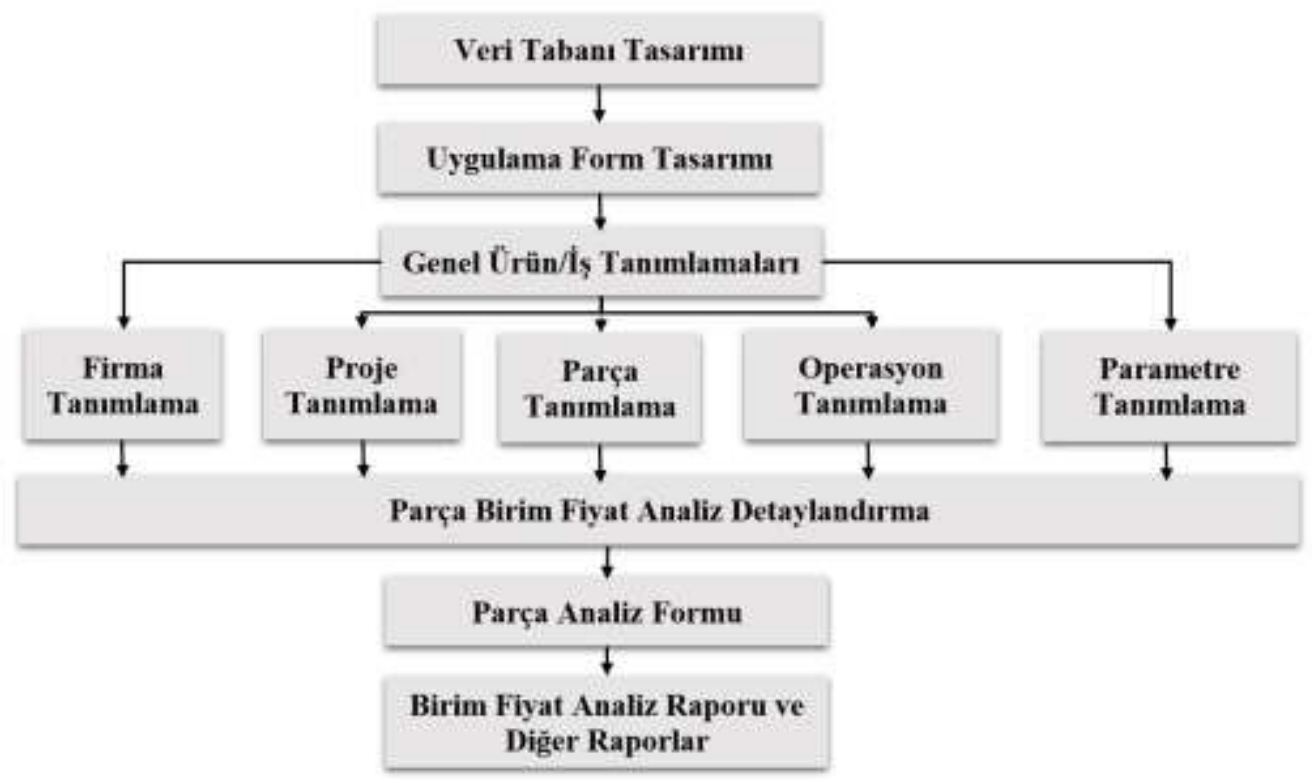

Şekil 1. Uygulama süreç akış1

Kaynak: Yazarlar

\subsubsection{Veri tabanı tasarımı}

Tabloların, alanların ve aralarındaki ilişkilerin belirlenmekte olduğu veri tabanı diyagramının oluştuğu kısımdır.

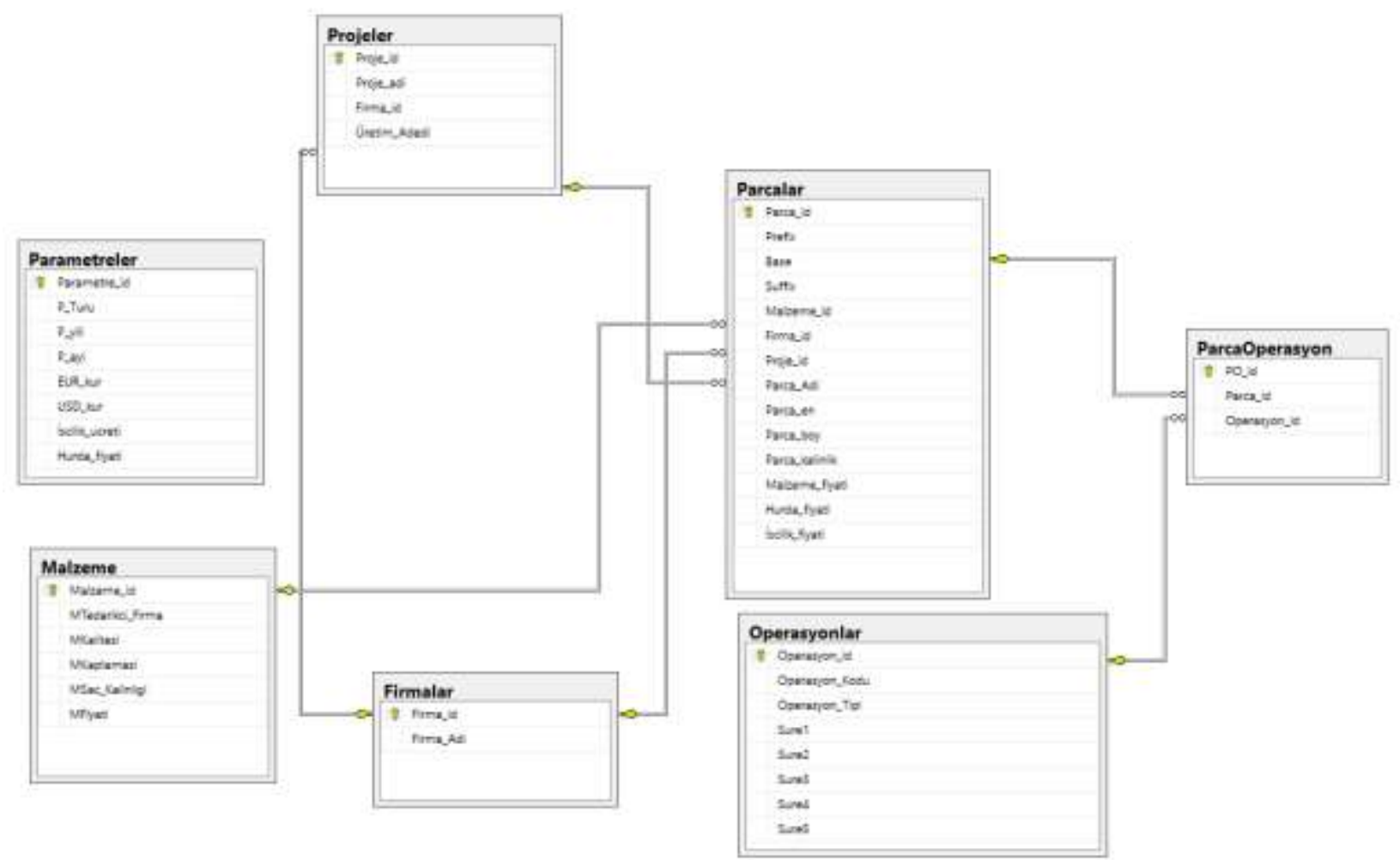

Şekil 2. Uygulama veri tabanı tasarımı

Kaynak: Yazarlar 


\subsubsection{Genel ürün/iş tanımlamaları}

$\mathrm{Bu}$ aşamada uygulamadaki birim fiyat analizi yapılacak parçanın temel bilgilerinin tanımlandığı formlar anlatılmıştır. Formdaki başlıklar; Proje Tanımlanması, Parça Tanımlaması, Firma Tanımlaması, Operasyon Tanımlaması, Parametre Tanımlaması şeklinde sıralanmıştır.

\subsubsection{Parça birim fiyat analiz detayları aşaması}

Bu adımda müşterinin fiyat teklifini beklediği parçaya ait fiyat hesaplaması için gerekli bütün verilere ait seçimlerin yapılması ve analizde işlenmesi gerekli olan bilgilerin girilmesiyle birim fiyatın oluşumu tamamlanmaktadır. Bu formda kendi arasında sekiz adım bulunmaktadır. Tüm bu adımlar fiyatı için gereken parametrik girdi verilerini oluşturmaktadır. $\mathrm{Bu}$ verilerden sonra arkada yapılmış olan hesaplarla grupların toplamları bir sonraki aşamada hesaplanmıştır.

\subsubsection{Birim fiyat analiz raporu}

$\mathrm{Bu}$ formdaki buton çalıştırıldığında birim fiyat özeti niteliğinde bir raporlama formu gösterilmiştir. Bu rapor organizasyon yöneticileri tarafınca karışıklığa sebebiyet vermeden oluşan fiyatın temel hatları ile yorumlanması ve hesaplama ara toplamlarının veri tabanında özet halinde kaydının yapılabilmesi yönünden sadece fiyat tutarlarını içeren bir tasarımdadır.

\section{BULGULAR}

Metodoloji bölümünde detayları anlatılan uygulama aşamaları sonucunda söz konusu işletme için işletme işleyişlerine katkı sağlayacak raporlardan üç tanesi aşağıda açıklanmıştır.

Uygulama, çalışmadaki açıklamalar içinde de söz edildiği üzere başka firmalardan üretiminin yapılması amaciyla istenen fiyat teklifi talebiyle birlikte iletilen ürün bilgilerine göre hazırlanacak olan fiyat hesaplamalarının sistemli halde hazırlanabilmesi için tasarlanmaktadır. Bunlarla beraber uygulama ana hedeflerinden olan ve işletmenin bazı süreç işleyişlerinin mevcut yapıdaki işleyişe göre fark edilebilir derecede hızlı ve sistematik şekle ulaştıran işletme iç ve dış bilgi akışının ve bunlara bağlı eylemlerinin gerçekleşmesi amaçlanmaktadır.

Oluşan parça fiyatının müşteri firma tarafına gönderilmesi ve fiyattaki anlaşmanın yapılarak prosedür belirlemelerinin gerçekleşmiş olduğu kabul edildikten sonra, parçayla alakalı diğer eylemlerin ve dolayısıyla işletme içiyle dışı ile yapılmak durumunda olan işlemlerin başlatılması gerekmektedir. 
Uygulama sonucu incelendiğinde hesaplanan birim fiyatla birlikte çalışma süresince bahsedilmekte olan işletme içi ve dışındaki iletişimlerdeki bilgi akışlarının planlanan zamanda ve veri kalitelerinin yüksek olduğu doğru bilgi şekline dönüşmüş şekilde bir döngü gerçekleşmesiyle örneklendirilmiş raporlar ile desteklendiği görülmektedir. Burada oluşan rapor çıktıları karar verme aşamasında yöneticilerin kararlarını hızlandırmak üzere yardımcı niteliklerde sonuçlanmış olacaklardır.

Tüm bu hedeflerin oluşumları için uygulama çıktısı niteliğinde alınacak rapor örneklerinde aşağıda bahsedilmektedir.

Tasarım İş Emri Raporu Örneği: Şirkette üretimin yapılması netleştirilen ürünün veya ürünlerin ilk olarak 3D çizimlerinin, işletmenin kullanmakta olduğu bilgisayar destekli üç boyut tasarım yazılımlarında, ilgili departman ekibince üretim simülasyonlarını oluşturacak analizlere başlanması için fiyat belirlemesinde öngörülmüş olan proseslerin ve ürün hakkında birtakım bilgiler dahilinde oluşturulması gerekli tasarım iş emri dokümanının ilgili birime gönderilmesi gerekmektedir.

$\mathrm{Bu}$ adımda var olan işleyiş içinde parça birim fiyat detaylarının bulunmakta olduğu excel dosyası içinden gereken bilgilerin manuel şekilde Word dokümanı formatına işlenerek bir üretim iş emri dokümanı oluşturulmaktadır.

Veriler bir dosya içinden alınıp başka bir dosya üzerine manuel şekilde kaydedilirken yapılabilecek hatalar ve görevli personelin görev birikimi ile işin ötelenmesinden kaynaklı söz verilen fiyat teklif termin zamanlarında yaşanabilecek problemler bu aşamadaki verimsiz ilerlemeye sebep olmaktadır. Bu vaziyet de teklif fiyatı hazırlanan ürünün üretiminde daha en başında planlandığı zaman dışında başlangıçlar yaşanarak gecikmelerle sonuçlanabilecektir.

Yaşanabilecek bu problem, uygulamanın fiyat raporu isimli formunda bulunan ilgili buton çalıştırıldığında pdf dokümanı halinde iş emri raporunu otomatik hazırlayarak alakalı personelin e-posta adresine iletilmesi sağlanıp çözümlenebilmektedir.

Malzeme Siparişi Rapor Örneği: Firmada fiyat teklifinde anlaşılarak üretimi yapılması kesinleșen ürünün uygulama içinde girilen malzeme bilgilerine göre firmanın satın alma biriminin malzeme siparişlerindeki zaman planlarını ve fiyat anlaşmasının sağlanması amacıyla belli bilgilerin içerildiği özet hazırlanarak gönderilmektedir. Bu özet içinde izlenmesi gerekli olan bilgiler; ürünün sac malzemesinin temin edileceği firma, tedarikçi firma spesifikasyonunda eşleştirilen malzeme kodu, sacın kalınlığ 
göre yılbaşına malzemenin kaçar ton ihtiyaç oluşturacağı olarak sıralanmaktadır. Mevcut durumda bu adım manuel girdilerle Excel dokümandan farklı bir doküman içinde özetlenip satın almayla paylaşılmaktadır.

Bir öncesindeki raporda da söz edildiği gibi veriler iki dosya arasında özetleme amacıyla manuel aktarım yapılırken karşılaşılabilecek yanlış veri özetleri oluşturma, üretim zamanına kadar etkileyecek şekilde planlanan zamandan farklı bir zamana gecikmeler yaşama, personelin diğer işlerinde dolayısıyla aksaklıklar meydana gelmesi gibi sorunlar sonucu verimli olmayan bir sürece dahil olmak kaçınılmaz olmaktadır.

Tüm bu problemlerin çözümü amaçlı oluşturulan uygulama ile; varılan aşama sonrasında daha ileriye taşınması üzere geliştirildiğinde, mevcut konularla alakalı gereklilik duyulan ve henüz burada örneklendirilmeyen başka raporlar oluşturularak bilgi sistemlerinin, teknoloji etkisiyle organizasyonlar üzerinde olumlu etkinin daha da genişleyebilir olduğu uygulamalı şekilde gözlemlenebilecektir.

\section{TARTIŞMA VE SONUÇ}

Organizasyonlarda gelecek kazanç planlamalarında etkili olan kararların alınmasında etkin rolde olan finansal bilgiler, sistemli bir temelde oluşturulmuş bir finansal bilgi sistemi içinde analiz edilerek gerçek finans raporlarına dönüşmesi işletme yönünden yüksek bir önem arz etmektedir.

Çalışmanın finansal bilgi sistemi açısından etkili ve etkin kullanımı kapsamında hazırlanmasıyla, otomotiv sektöründeki örnek firma üzerinde hem mevcutta yapılması gereken iş detaylarının otomatize hale getirilmesi hem de yapılan bu detaylara bağımlı olarak gerçekleştirilmesi gerekli iş akışları yürütülürken diğer departmanlar ile olan iletişimin de gerçekleştirilmesi amaçlanmıştır. Firma ihtiyaçları dâhilinde teknolojik yöntemlerin doğru müdahale edilerek bilgi sistemleri kapsamı dâhilinde yazılım tabanlı bir iyileşmeyle birlikte kullanımı firmanın olumlu yönde gelişmesini sağlamıştır.

Organizasyonda süregelen işleyiş dâhilinde işletmeye diğer firmalar tarafından gönderilen, belli proje kapsamında üretimi talep edilen ürünlerin fiyat teklif istekleri gelmekte ve buna bağlı fiyat hesaplamaları yapılmaktadır. Mevcutta yapılan hesaplarda el ile veri girildiği için hesaplamalarda oluşan hatalarla, geçmiş kayıtlardaki benzer ürün fiyatlarının mukayese edilebilmelerinde karşılaşıllan eksiklikler gibi benzeri sorunlardan dolayı teklif istek terminlerinde gecikme veya veri kayıplarının oluşması ile karşılaşılmıştır. Bu sonuçlar ile 
işletmelere verilmekte olan fiyat tekliflerinin kendi aralarındaki tutarlılık bozulmaya başlamakta, ortaya çıkan hesaplamalarda veya bu bahsedilen tutarsızlıklardan kaynaklı teklif isteklerinin termin tarihleri hakkındaki aksamalar gibi etmenler firmanın sektör profilinin olumsuz yönde etkilenmesine sebep olmaktadır. Ayrıca maliyetlendirme konularında yaşanmış olan problemler bilgi iletimi gereken firma birimlerinin de bilgi alması yönünde aksamalara sebep olabilmektedir.

Yapılan uygulama işlevsel olarak gereken yazılımlardan yararlanılarak tasarlanmıştır. Bununla hesaplamalar için gereken verinin manuel girdileri ve raporların oluşmasındaki manuel veri girişlerinde azaltma uygulanarak hata alma olasılıkları düşürülmektedir. Ayrıca geçmiş hesaplamalardaki ürünün birim fiyatının analizine erişim kolaylığı gerçekleştirilmiş, bu sebeple de benzer parçaların teklif detaylarındaki tutarlılık seviyesi artırılmış duruma getirilmiştir. Fiyat teklifi hazırlanan ve anlaşma dâhilinde üretimi planlanmış olan ürün ile alakalı olarak firma içinde aksiyon alımı için diğer birimlere iletilmek üzere oluşturulan rapor dokümanlarının, e-posta yoluyla manuel veri girişleri ile hazırlanması ve gönderimi yerine; bahsedilen iş tanımları amacıyla oluşturulan komutlarla otomatik e-posta gönderimi hatalı veri aktarım olasılığını azaltmıştır.

İşletmelerde yönetimin bulunduğu kademede karar alma aşamalarında gereklilik duyulan finansal bilgilerin hızla edinilmesi, gelecek zamanlara yönelik ve daha doğru bilgi topluluklarının karşılanabildiği bilgi akışlarını gerçekleştiren sistemlerin kurulması organizasyonların önemli gelişimlerini oluşturmaktadır (Şakrak, 2009: 51).

Benzeyen farklı bir açıklamaya göre ise finansal bilgi sistemleri, kullanıcılar yönünden gerekli görülen bilginin, gereken zamanlarda ve doğru bilgi şeklinde sağlanmasıyla karar alma konularında kolaylaştırıcı olmaktadır. Bahsedilen bu kararlar rutin ya da ürünün ya da hizmetin yelpazesinin artırımı veya organizasyonun zararda ilerlediği ürünün ya da hizmet üretiminin durması gibi stratejik kararlardan da olabilir (Kaygusuzoğlu ve Uluyol, 2011: 304).

Finansal bilgi sistemi bütününde hazırlanmış olan uygulama çıktılarından olan finansal raporlar tarafından, işletme içi yönetimsel kararlardaki doğruluk, hızlılık ve verimlilik vb. parametrelerinin sağlandığı etkilerin sonucu ile birlikte işletmedeki departmanlar arası gereken iletişimin de kolaylığının sağlandığı ve bununla beraber alınacak kararların işletme ortak amaçları kapsamında alınması yönünde etkilediği görülmüştür. Bahsi geçen bütün süreçler üzerinde optimizasyon sağlanıp işin süreçleri sistematize edilip bütünleşme sağlanmıştır. 
Yapılmış olan çalışma içinde; organizasyondaki işlemler arası yaşanan gecikme ve kayıpların oluşmasına sebebiyet veren, geleneksellikle yürütülmekte olan bir operasyon adımının otomatize edilerek kendinden sonra olan disiplinlere veri/bilgi geçişlerini sağlayacak işin süreçlerinin entegrasyonu sağlanmıştır. Bunların sonucu ile bütün birimleri içinde bulunduran bu bütünleşmiş yapı ile işlerle alakalı anlık ve daha gerçekçi raporlar elde edilerek yöneticinin daha rasyonel karar alınması sağlanmaktadır. Bu sonuç ile gerçekleşen işlerin etkinlik, hız ve verimlilikleri artırılmış olur. Uygulama üzerinden ise çalışma içinde örneklendirme yapılmamış farklı raporlar yaratılarak bilgi sistemleri için teknoloji kullanımındaki olumlu organizasyon etkileri genişletilebilmekte ve bir kurumsal kaynak planlama yapısı oluşturulup bütün birimlerin detaylandırılmış bir kapsam üzerinde değerlendirildiği entegre halde çalışma öngörülmüştür.

\section{REFERENCES / KAYNAKLAR}

Akdoğan, N. \& Tenker, N. (2001). Finansal tablolar ve mali analiz teknikleri. Ankara: Gazi Kitabevi.

Aksay, K. (2015). Örgüt yapılarında yaşanan değişimler ve modern örgüt tiplerinin incelenmesi. Kent Akademisi Dergisi, 8(23), 111-128.

Alagöz, A., Öge, S. \& Koçtiğit, N. (2013). Muhasebe bilgi sistemi ve karar destek sistemleri ilişkisinin yönetsel karar alma faaliyetlerine etkisi. Selçuk Üniversitesi Sosyal Bilimler Enstitüsü Dergisi, (30), 27-40.

Bagranoff, N. A., Simkin, M. G. \& Strand, C. (2005). Core concepts of accounting informations systems. New Jersey, ABD: John Wiley Sons.

Bekçi, İ. \& Alkan, H. (2009). Finansal bilgi sisteminin hisse senetlerine yatırım kararı üzerine etkisi: İMKB'de bir uygulama. Süleyman Demirel Üniversitesi İktisadi ve İdari Bilimler Fakültesi, 14(3), 1-20.

Bölükoğlu, İ. \& Birgili, E. (1992). Finansal bilgi sisteminin modern işletme yönetimindeki rolü ve önemi. Dokuz Eylül Üniversitesi I.I.B.F. Dergisi, 7(1), 63-75.

Çubukçu, M. (2018). Organizasyon yapısını belirleyen faktörler ve yapının önemi. Adnan Menderes Üniversitesi Sosyal Bilimler Enstitüsü Dergisi, 5(2), 175-190.

Demir, A. (1996). Mali tablolar ve uygulaması. İstanbul: Çağdaş Yayınları.

Demir, Y. \& Coşkun, D. (2009). Finansal bilgi sisteminin işletmelerin yönetim fonksiyonu üzerine etkisi: Aydın ili örneği. Uşak Üniversitesi Sosyal Bilimler Dergisi, 2(2), 1-21.

Güney, C. (2014). Sanal organizasyonlarda iç kontroller. Denetim Dergisi, 27(127/128), 4-12.

Karahan, A. (2008). Çalışanların örgüt kültürünü algılamalarına yönelik ampirik bir çalışma. Selçuk Üniversitesi Sosyal Bilimler Enstitüsü Dergisi, (20), 457-478.

Kaygusuzoğlu, M. \& Uluyol, O. (2011). İşletme yöneticilerinin muhasebe bilgilerini kullanım düzeyinin araştırılması ve Adıyaman uygulaması. Yönetim Bilimleri Dergisi, 9(2), 299-320. 
Laudon, K. C. \& Laudon, J. P. (2014). Yönetim bilişim sistemleri-dijital işletmeyi yönetme (U. Yozgat, Çev.). Ankara: Nobel Akademik Yayıncılık.

Morgül, T. (2013). Finansal disiplinin temel ilkeleri. Erişim Tarihi: 15.04.2019, https://www.academia.edu/8241401/Finansal_Disiplinin_Temel_\%C4\%B0lkeleri.

Onat, F. (2007). Bilişim teknolojilerinin yaygınlaşması ile değişen örgüt yapılarında halkla ilişkilerin rolü: Network örgüt yapılarına yönelik bir çalışma (Doktora tezi). Ege Üniversitesi, İzmir.

Şakrak, M. (1999). Kriz döneminde muhasebe bilgi sisteminin rolü. Muhasebe-Finans Araştırma ve Uygulama Dergisi, 8(10), 43-58.

Usul, H. \& Bekçi, İ. (2001), Bireysel yatırımcılar açısından finansal bilgi sisteminin sermaye ve piyasasında etkinliğinin analizi. C. Ü. İktisadi ve İdari Bilimler Dergisi, 2(1), 67-79.

Yılmaz, H. (1999). İşletmelerde finans karar destek sistemi. Dokuz Eylül Üniversitesi Sosyal Bilimler Enstitüsü Dergisi, 1(1), 52-66. 